\title{
Pemanfaatan Tepung Biji Pepaya (Carica papaya) Terhadap Respons Pertumbuhan dan Tingkat Kelangsungan Hidup Ikan Nila (Oreochromis niloticus)
} Aprelia Martina Tomasoaa*, Deidy Azharia aTeknologi Budidaya Ikan, Jurusan Perikanan dan Kebaharian, PolNustar

K A T A K U N I

Biji pepaya

Ikan nila

Pepaya
Pertumbuhan

\begin{abstract}
A B S T R A K
Laju pertumbuhan dan tingkat reproduksi yang tinggi merupakan karakteristik unggul yang dimiliki ikan nila sebagai komoditi budidaya. Tingkat reproduksi yang tinggi menyebabkan terjadinya pematangan gonad sebelum mencapai ukuran produksi dimana hal tersebut dapat merugikan pembudidaya, karena saat ikan mengalami matang gonad energi hasil asimilasi pakan sebagain besar akan dialokasikan untuk perkembangan gonad dan menghambat pertumbuhan somatik. Pemanfaatan senyawa aktif dari bahan alami biji pepaya dapat menjadi solusi untuk meningkatkan pertumbuhan ikan yang dibudidayakan sekaligus menjaga keamanan pangan dan konsumen. Penelitian ini bertujuan untuk mengetahui pemanfaatan tepung biji pepaya terhadap respons pertumbuhan dan tingkat kelangsungan hidup ikan nila. Ikan nila diberi perlakuan dengan lima dosis tepung biji pepaya berbeda $(0,1,3,5$ dan $7 \mathrm{~g} / \mathrm{kg}$ pakan) secara oral berdasarkan feeding rate $5 \%$ dengan tiga ulangan selama 30 hari pemeliharaan. Hasil penelitian menunjukkan dosis $5 \mathrm{~g} / \mathrm{kg}$ meningkatkan pertumbuhan bobot tubuh tertinggi sebesar $547 \mathrm{~g}$ dibandingkan kontrol sebesar 406 g. Sejalan dengan pertumbuhan bobot tubuh, dosis $5 \mathrm{~g} / \mathrm{kg}$ menghasilkan tingkat kelangsungan hidup ikan nila sebesar $100 \%$ dibandingkan kontrol sebesar $66 \%$. Dari hasil yang diperoleh dapat disimpulkan bahwa tepung biji pepaya dengan dosis $5 \mathrm{~g} / \mathrm{kg}$ pakan dapat meningkatkan pertumbuhan dan tingkat kelangsungan hidup ikan nila selama 30 hari.
\end{abstract}

K E Y W O R D S

\section{A B S T R A C T}

Carica papaya

Growth

Papaya seed

Tilapia
High growth rate and high reproductive cycle are some economical triats on nile tilapia. This is a setback for nile tilapia culture because when the fish reach gonad maturity before reach market size, all the energy demand will flow to reproduction and can cause stunt growth. The utilization of natural compound from papaya seeds can be a solution to enhance growth of farmed nile tilapia and for consumer and food safety. This research aim to know how papaya seed powder can enhance growth and survival rate of nile tilapia. This research conducted into five groups of 5 papaya seeds powder dosage $(0,1,3,5$ and $7 \mathrm{~g} / \mathrm{kg})$ that feed orally to the treatment fishes. Result showed the fishes feed with $5 \mathrm{~g} / \mathrm{kg}$ papaya seed experienced highest growth performance $547 \mathrm{~g}$ compare to control which is 406 g. Same as growth performance, survival rate shown that group feed with 5 $\mathrm{g} / \mathrm{kg}$ papaya seed had $100 \%$ survival rate compare with control which is $66 \%$ during treatment periods. Base on this result, we can make conclusion that fish feed with $5 \mathrm{~g} / \mathrm{kg}$ of papaya seed have a better growth performance and survival rate compare with control group for 30 days treatment periods.

\begin{tabular}{l}
$\frac{\text { TERSEDIA ONLINE }}{31 \text { Okotober } 2019}$ \\
\hline $\begin{array}{l}\text { Pendahuluan } \\
\text { Ikan dimanfaatkan sebagai bahan pangan karena }\end{array}$ \\
mengandung nilai gizi berupa protein, lemak, vitamin
\end{tabular}

dan mineral. Salah satu jenis ikan yang dimanfaatkan sebagai bahan pangan dan menjadi komoditi budidaya adalah ikan nila (Oreocromis niloticus). Ikan nila merupakan jenis ikan air tawar yang paling banyak

*Corresponding author: Teknologi Budidaya Ikan, Jurusan Perikanan dan Kebaharian, Politeknik Negeri Nusa Utara, Jl. Kesehatan No. 1, Tahuna, Indonesia 95812;

Email address: apriltomasoa@gmail.com

Published by FMIPA UNSRAT (2019) 
dibudidayakan di Indonesia termasuk di Kepulauan Sangihe. Menurut Burham \& Bahar (2006) ikan nila menduduki urutan kedua setelah ikan mas dalam produksi budidaya air tawar di Indonesia.

Pusdatin KKP (2014), melaporkan bahwa produksi ikan nila di Indonesia meningkat dari 567.078 ton pada tahun 2012 menjadi 1.604.810 ton pada tahun 2013. Hal ini menunjukkan bahwa ketertarikan masyarakat terhadap ikan nila sebagai komoditi budidaya terus berkembang diberbagai daerah. Data Puslat KP (2013), menunjukkan bahwa produksi ikan nila di Sulawesi Utara pada tahun 2012 mencapai 32\% (33.000 ton) dibandingkan tahun 2011 yang hanya 25.000 ton.

Ikan nila memiliki beberapa karakteristik unggul untuk dibudidaya, yaitu pakan yang bervariasi, rentang toleransi lingkungan yang luas, tahan terhadap hama penyakit (Gupta \& Acosta, 2004), laju pertumbuhan dan tingkat reproduksi yang tinggi (Soelistyowati et al., 2010). Salah satu karakteristik unggul ikan nila yaitu tingkat reproduksi yang tinggi dapat menjadi suatu ancaman kerugian bagi budidaya ikan nila. Tingkat reproduksi yang tinggi menyebabkan terjadinya kematangan gonad sebelum mencapai ukuran produksi sesuai pasaran dan dapat menurunkan kualitas benih dengan ketidakseragaman ukuran (Peterson et al., 2004). Hal ini dapat dicegah dengan melakukan pengontrolan laju reproduksi ikan nila sehingga dapat meningkatkan pertumbuhan bobot tubuh.

Berbagai penelitian telah dilakukan untuk meningkatkan produksi pascapanen dalam hal peningkatan pertumbuhan. Penggunaan senyawasenyawa dari bahan alami berpotensi untuk digunakan sekarang sedang giat dilakukan dalam produksi pangan untuk menjaga kesehatan konsumen dan keamanan lingkungan (Gupta \& Acosta, 2004). Salah satunya adalah penggunaan biji pepaya karena mengandung senyawa-senyawa aktif yang dapat meningkatkan pertumbuhan. Tanaman pepaya dikenal secara tradisional sebagai bahan baku pengobatan dan mengandung senyawa metabolit primer (Yuniwati \& Purwanti, 2008).

Di Kepulauan Sangihe banyak ditemukan tanaman pepaya dan biji pepaya biasanya tidak termanfaatkan. Biji pepaya mudah dijumpai, biaya lebih murah dan ramah lingkungan sehingga biji pepaya dapat dimanfaatkan dengan memanfaatkan senyawasenyawa aktif bagi kebutuhan ikan budidaya. Pemanfaatan biji pepaya dalam bentuk tepung pada penelitian ini bertujuan untuk mengetahui respons pertumbuhan dan tingkat kelangsungan hidup ikan nila.

\footnotetext{
Material dan Metode

Alat dan Bahan

Peralatan yang digunakan berupa akuarium, instalasi aerasi, top filter, blender, ayakan tepung, loyang, gelas ukur, timbangan digital, sendok dan alat cetak pelet. Sedangkan bahan-bahan yang digunakan berupa ikan nila, biji pepaya yang matang, pakan komersil MG-3, kecap ikan dan air secukupnya.
}

\section{Persiapan Ikan dan Wadah}

Ikan yang digunakan adalah ikan nila berukuran 15-20 g/ekor dengan kondisi tubuh tidak cacat dan luka. Ikan nila dilakukan aklimatisasi selama 1 minggu sebelum ditebar dan diberi perlakuan. Dalam penelitian ini menggunakan akuarium sebagai wadah pemeliharaan berukuran $60 \times 40 \times 50$ $\mathrm{cm}^{3}$ sebanyak 15 unit. Setiap akuarium ikan ditebar sebanyak 15 ekor. Akuarium dilengkapi dengan instalasi aerasi dan top filter.

\section{Pembuatan Tepung Biji Pepaya}

Buah pepaya yang digunakan adalah buah pepaya yang sudah benar-benar matang, buah pepaya dipreparasi dan diambil bijinya. Setelah dibersihkan biji pepaya dijemur di bawah sinar matahari selama \pm 3 hari. Setelah kering biji pepaya diblender dan diayak untuk memperoleh tepung biji pepaya.

\section{Repelleting Pakan}

Repelleting pakan menggunakan pakan komersil MG-3 dengan kadar protein 20\% diblender dan diayak sampai menjadi tepung. Tepung pakan ditambahkan dengan tepung biji pepaya sebanyak 0 g, 1 g, 3 g, 5 g dan 7 g/kg serta ditambahkan kecap ikan. Setelah itu tambahkan air secukupnya sampai membentuk adonan dan dicetak kembali seperti pellet. Kemudian pellet dijemur sampai kering dan disimpan dalam wadah tertutup sebelum diberikan pada ikan.

\section{Pemeliharaan Ikan dan Pengambilan Data}

Selama proses pemeliharaan 30 hari ikan nila diberi makan dengan pakan sesuai perlakuan dosis tepung biji pepaya. Ikan diberi pakan berdasarkan feeding rate $5 \%$ dari total bobot tubuh 2 kali sehari pada pagi dan sore hari. Setiap 3 hari dilakukan pergantian air akuarium untuk menjaga kualitas air tetap optimal.

Pengambilan data yang dilakukan selama penelitian yaitu pertumbuhan bobot tubuh dan tingkat kelangsungan hidup ikan nila selama 30 hari. Pengambilan data pertumbuhan dilakukan setiap 10 hari dan persentasi tingkat kelangsungan hidup pada awal dan akhir pemeliharaan. Nilai pertumbuhan dihitung dengan persaman W (Effendie, 1997) dan tingkat kelangsungan hidup dihitung dengan persamaan SR (Effendie, 1997).

$$
\mathrm{W}=\mathrm{W}_{\mathrm{t}}-\mathrm{W}_{\mathrm{o}}
$$

Keterangan :

$$
\begin{aligned}
& \mathrm{W}=\text { Pertumbuhan bobot tubuh (g) } \\
& \mathrm{W}_{\mathrm{t}} \quad=\text { Bobot ikan akhir pemeliharaan (g) } \\
& \mathrm{W}_{0} \quad=\text { Bobot ikan awal pemeliharaan }(\mathrm{g}) \\
& \mathrm{SR}=\frac{N t}{N 0} x 100 \%
\end{aligned}
$$

Keterangan :

$$
\begin{array}{ll}
\mathrm{SR} & =\text { Survival Rate (\%) } \\
\mathrm{N}_{\mathrm{t}} & =\text { Jumlah ikan akhir pemeliharaan (ekor) } \\
\mathrm{N}_{\mathrm{o}} & =\text { Jumlah ikan awal pemeliharaan (ekor) }
\end{array}
$$

\section{Hasil dan Pembahasan}

Hasil penelitian yang didapat berupa pertumbuhan bobot tubuh dan tingkat kelangsungan hidup ikan nila 
yang diberi pakan tepung biji pepaya selama 30 hari dapat dilihat pada Gambar 1 dan 2.

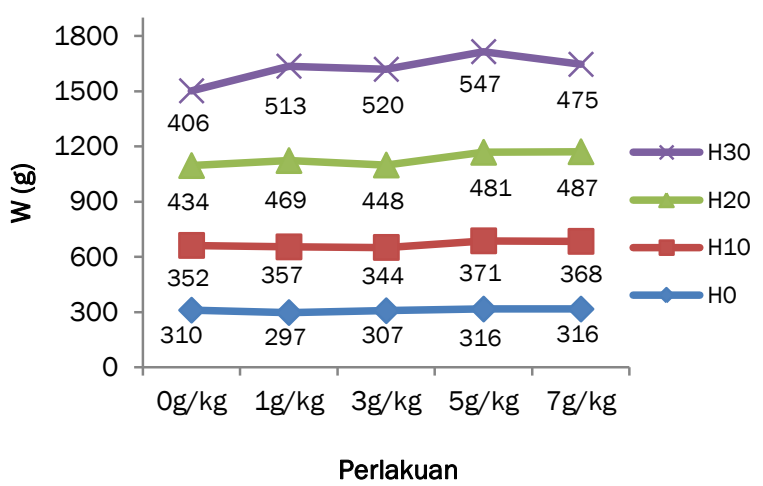

Gambar 1. Pertumbuhan bobot tubuh ikan nila yang diberi pakan tepung biji pepaya selama 30 hari.

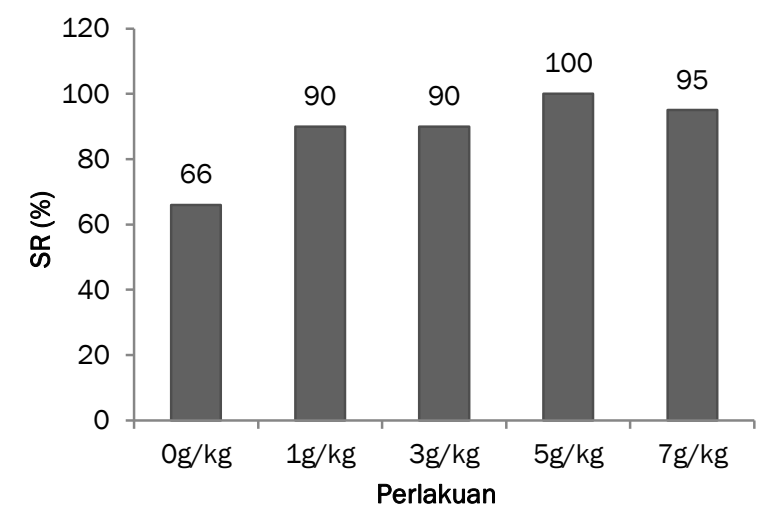

Gambar 2. Tingkat kelangsungan hidup ikan nila yang diberi pakan tepung biji pepaya selama 30 hari.

Gambar 1 menunjukkan hasil pengukuran bobot tubuh ikan nila selama 30 hari yang diberi perlakuan pakan tepung biji pepaya mengalami peningkatan dari hari ke-0 sampai hari ke-30. Peningkatan pertumbuhan bobot tubuh yang tertinggi pada perlakuan dosis tepung biji pepaya $5 \mathrm{~g} / \mathrm{kg}$ sebesar $547 \mathrm{~g}$ diikuti oleh perlakuan dosis $3 \mathrm{~g} / \mathrm{kg}$ sebesar $520 \mathrm{~g}$, dosis $1 \mathrm{~g} / \mathrm{kg}$ sebesar 513 $\mathrm{g}$, dosis $7 \mathrm{~g}$ sebesar $475 \mathrm{~g}$ dibandingkan dengan dosis 0 $\mathrm{g} / \mathrm{kg}$ sebesar $406 \mathrm{~g}$.

Pertumbuhan ditandai dengan bertambahnya bobot dan panjang tubuh. Bobot tubuh pada ikan nila selama penelitian disebabkan oleh kenaikkan masa daging yang diperoleh dari asimilasi pakan yang dimakan. Ikan nila memperoleh energi dari pakan dengan memanfaatkan nutrisi seperti protein, lemak, karbohidrat, vitamin dan mineral. Menurut Anggraeni (2013) menyatakan bahwa pertumbuhan ikan memiliki kaitan yang erat dengan ketersediaan protein dalam pakan karena protein merupakan sumber energi dan nutrisi yang paling dibutuhkan ikan dalam tahap pertumbuhan.

Krishna et al. (2008) dalam penelitiannya mengemukakan bahwa bagian buah pepaya termasuk biji pepaya mengandung enzim yang dapat digunakan sebagai nutrisi dan obat. Enzim papain yang terkandung dalam biji pepaya merupakan enzim proteolitik (Hutabarat et al., 2015) yang dapat menghidrolisis protein menjadi asam amino. Hal ini sejalan dengan hasil penelitian dimana protein dalam pakan diserap oleh ikan dan energi yang diperoleh akan lebih banyak sehingga ikan mengalami pertumbuhan bobot tubuh. Selain itu penentuan dosis tepung biji pepaya yang digunakan juga sangat penting. Penentuan dosis yang tepat akan berhubungan dengan proses pemecahan protein, semakin cepat proses tersebut maka semakin cepat penyerapan asam amino dalam tubuh ikan (Sari \& Andriani, 2018).

Hasil pertumbuhan bobot tubuh dalam penelitian ini sejalan dengan beberapa hasil penelitian yang menggunakan bagian dari tanaman pepaya. Isnawati et al. (2015) menggunakan serbuk daun pepaya sebanyak $2 \%$ dapat meningkatkan efisiensi pakan sebesar $36,65 \%$, rasio efisiensi protein sebesar $0,55 \%$ dan laju pertumbuhan relatif sebesar $2,725 \%$ dan kandungan protein daging ikan nila sebesar $17,98 \%$. Sari \& Andriani (2018) melakukan pemberian getah pepaya dengan perlakuan terbaik sebesar 3,25\% dapat meningkatkan laju pertumbuhan bobot tubuh $10,04 \mathrm{~g}$ dan panjang tubuh 2,50 cm ikan gurami.

Tiingkat kelangsungan hidup merupakan persentase perbandingan jumlah ikan yang hidup diakhir masa pemeliharaan dengan jumlah ikan yang hidup diawal masa pemeliharaan. Persentase tingkat kelangsungan hidup ikan yang baik mencapai $>50 \%$ dan tidak baik jika hanya mencapai 30\% (Mulyani et al., 2014). Tingkat kelangsungan hidup dapat dipengaruhi oleh beberapa faktor diantaranya ketersediaan pakan dan kualitas media pemeliharaan yang baik.

Hasil penelitian tingkat kelangsungan hidup ikan nila (Gambar 2) menunjukkan persentase tertinggi pada perlakuan dosis tepung biji pepaya $5 \mathrm{~g} / \mathrm{kg}$ sebesar $100 \%$ diikuti perlakuan dosis $7 \mathrm{~g} / \mathrm{kg}$ sebesar 95\%, perlakuan dosis $1 \mathrm{~g} / \mathrm{kg}$ dan $3 \mathrm{~g} / \mathrm{kg}$ sebesar $90 \%$ dibandingkan dengan perlakuan kontrol sebesar $66 \%$. Dalam penelitian ini tingkat kelangsungan hidup ikan nila yang diberi tepung biji pepaya dalam kategori baik karena semua perlakuan mencapai $>50 \%$.

\section{Kesimpulan \\ Hasil penelitian ini dapat disimpulkan bahwa penggunaaan tepung biji pepaya dalam pakan memberikan pengaruh terhadap pertumbuhan bobot tubuh dan tingkat kelangsungan hidup ikan nila. Perlakuan tepung biji pepaya dosis $5 \mathrm{~g} / \mathrm{kg}$ merupakan perlakuan dosis terbaik dapat meningkatkan pertumbuhan bobot tubuh sebesar $547 \mathrm{~g}$ dan tingkat kelangsungan hidup ikan nila mencapai $100 \%$ selama 30 hari pemeliharaan.}

\section{Daftar Pustaka}

[Pusdatin KKP] Pusat Data dan Informasi Kementrian Kelautan Perikanan. 2014. Statistik kelautan dan perikanan 2013. Kementrian Kelautan Perikanan.

[Puslat KP] Pusat Pelatihan Kelautan dan Perikanan. 2011. Produksi ikan nila. Kementrian Kelautan Perikanan.

Anggraeni, N.M dan Abdulgani, N. 2013. Pengaruh Pemberian Pakan Alami dan Buatan Terhadap Pertumbuhan Ikan Betutu (Oxyeleotris marmorata) pada Skala Laboratorium. Jurnal Sains Dan Seni Pomits 2(1): 2337-3520. 
Burham dan Bahar. 2006. Panduan Praktis Memilih dan Menangani Produk Perikanan. PT Gramedia Pustaka Utama, Jakarta.

Effendie M. I. 1997. Biologi Perairan. Yayasan Pustaka Nusantara, Yogyakarta.

Gupta, V. M., and Acosta B. O. 2004. A Review of Global Tilapia Farming Practices. Aquaculture Asia 9 (1): 7-12.

Hutabarat, G. M., Rahchmawati, D., dan Pinandoyo. 2015. Performa Pertumbuhan Benih Lobster Air Tawar (Cherax quadricarinatus) Melalui Penambahan Enzim Papain Pada Pakan Buatan. Journal of Aquaculture Management and Technology 4(1): 10-18.

Isnawati, N., Sidik R., dan Mahasri G. 2015. Potensi Serbuk Daun Pepaya Untuk Meningkatkan Efisiensi Pemanfaatan Pakan, Rasio Efisiensi Protein dan Laju Pertumbuhan Relatif Pada Budidaya Ikan Nila (Oreochromis niloticus). Jurnal IImiah Perikanan dan Kelautan 7(2): 121124.

Krishna, K. L., Paridhawi, M., and Patel, J. A. 2008. Review on Nutritional, Medicinal and Pharmacological Properties of Papaya (Carica papaya Linn.) Natural Product Radiance 7(4): 364-373.

Peterson, M.S., Brown-Peterson, N. J., McDonald, J. L. 2004. Reproduction in Non-native Environments: Establishment of the Nile Tilapia Oreochromis niloticus in Coastal Mississippi Water-sheds. Copeia : 842-849.

Sari, M. P dan Adriani D. 2018. Pengaruh Pemberian Getah Pepaya Dengan Dosis Yang Berbeda Pada Pakan Terhadap pertumbuhan Benih Ikan Gurame (Osphoronemous gouramy). Fiseries 7 (1): 24-31.

Soelistyowati, D. T., Sudrajat, A. O., dan Arfah, H. 2010. Maskulinisasi Pada Ikan Nila Merah (Oreochromis sp.) Menggunakan Bahan Alami Resin Lebah Melalui Pakan Buatan. Jurnal Akuakultur Indonesia 9(2): 178-183.

Yuniwati, M dan Purwati, A. 2008. Optimasi Kondisi Proses Ekstraksi Biji Pepaya. Jurnal Teknologi Technoscientia 1(1): 75-82. 